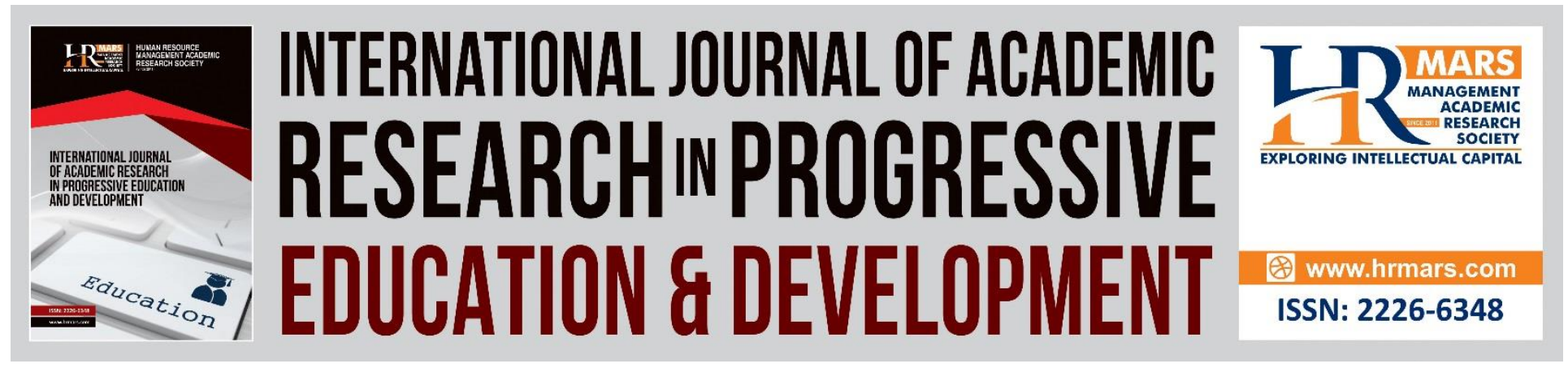

\title{
Validity and Reliability of the Health Education Assessment Module (MoPPK) among Primary Students in Malaysia
}

Faiznur Maisya Binti Annur Sani, Azali Bin Rahmat \& Gunathevan a/l Elumalai

To Link this Article: http://dx.doi.org/10.6007/IJARPED/v10-i1/8378 DOI:10.6007/IJARPED/v10-i1/8378

Received: 03 December 2020, Revised: 04 January 2021, Accepted: 17 January 2021

Published Online: 16 February 2021

In-Text Citation: (Sani et al., 2021)

To Cite this Article: Sani, F. M. B. A., Rahmat, A. Bin, \& Elumalai, G. a/I. (2021). Validity and Reliability of the Health Education Assessment Module (MoPPK) among Primary Students in Malaysia. International Journal of Academic Research in Progressive Education and Development, 10(1), 130-138.

Copyright: (C) 2021 The Author(s)

Published by Human Resource Management Academic Research Society (www.hrmars.com)

This article is published under the Creative Commons Attribution (CC BY 4.0) license. Anyone may reproduce, distribute, translate and create derivative works of this article (for both commercial and non-commercial purposes), subject to full attribution to the original publication and authors. The full terms of this license may be seen at: http://creativecommons.org/licences/by/4.0/legalcode

Vol. 10(1) 2021, Pg. 130 - 138

http://hrmars.com/index.php/pages/detail/IJARPED

JOURNAL HOMEPAGE

Full Terms \& Conditions of access and use can be found at http://hrmars.com/index.php/pages/detail/publication-ethics 


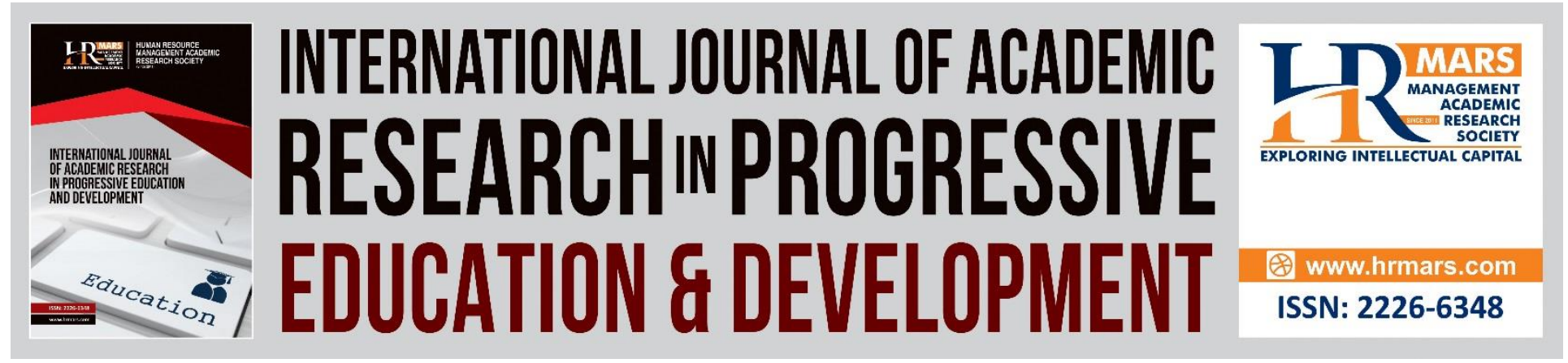

\title{
Validity and Reliability of the Health Education Assessment Module (MoPPK) among Primary Students in Malaysia
}

\author{
Faiznur Maisya Binti Annur Sani, Azali Bin Rahmat \& Gunathevan \\ a/l Elumalai \\ Faculty of Sports Science \& Coaching, Universiti Pendidikan Sultan Idris, Malaysia
}

\begin{abstract}
The study was conducted to obtain the validity and reliability of the Health Education Assessment Module. It is developed for the teachers to learn and facilitate the teaching of topics on the subjects of Health Education on the Malaysian school syllabus. The design of the study is quantitative and the survey method is used to collect data. The MoPPK module has been certified by thirteen experts in the relevant fields of Health Education and eight experts from Malay Language. A total of 40 primary students from standard four from Georgetown Penang Division were selected to test the reliability of the module activity by evaluating the effectiveness of assessment after teaching session of every topic in related subjects. The findings show that the module has a good validity of $88.77 \%$ with the value of Alpha Cronbach .825. While, the value of reliability is in high range which is .969 . However, some aspects need to be improved so that the developed module can achieved the purposed for which it has been designed. The findings of the study would be useful to other researchers who intend to develop other assessment modules based on the ADDIE Model. In conclusion, the researcher hopes that this module will help the students in learning and teachers in evaluating students understanding.
\end{abstract}

Keywords: Validity, Reliability, Health Education Assessment Module

\section{Introduction}

In Malaysia, students understanding is evaluated based on their grades through examination. Therefore, in order to be successful in achieving expected objectives outcomes for every subjects, it is essential to access student learning often. In education, assessment is often used to describe the measurement of what an individual knows and can dap (Banta \& Palomba, 2015). Assessment also provide immediate feedback for teachers to improve teaching techniques according to the learning styles of their students. Formative assessment is frequent interactive assessment of student progress to identify learning needs and feedback teaching skills appropriately (Looney, 
2009). While summative assessment is an appraisal learning at the end of every sub unit to compares student knowledge or skills against standards (States, Detrich, \& Keyworth, 2018).

Health education context can, however, provide assessment challenge for educators in order to set academic standard or learning targets, indicating what students understand an applied as a result of instruction. Nowadays, there is no standardized module that has been used to access students understanding in health education (Rahmat, Jani, Salimin, Khalid, \& Salleh, 2012). Therefore, an effective classroom assessment should occur including variety of methods, providing student achievement records and descriptive feedback to the student. It is necessary that the student noted the objectivity of learning and the assessment criteria to work toward proficiency with their teachers. Both teachers and students will take their responsibility for learning and teaching skills to improve their instruction.

In the 21st century learning, students are required to enhance their skills in problem solving, decision making, team work and communication with teaches guidance. According to National Education Blueprint 2013-2025, Malaysia's education has been transformed to produce human capitals that can cope with 21st century world challenges (Ministry of Education Malaysia, 2013)

Thus, in order to cope with the world challenges, teachers play a very important role to produce students who are equipped with the skills needed. According to Smaldino, Lowther, and Russell (2012), PAK-21 emphasizes three main components of learning, namely teaching strategies, variety of learning contexts and technology integration, and media and materials to support teaching and learning.

Based on the identified problems, the researchers have developed an assessment module for every Health Education topic in standard 4 with the support of text book and syllabus based on education curriculum standard documents. The development of the current module is guided in the instructional systems design (ISD) which is ADDIE model as elaborated by Rosset (1987). The validity and reliability of the assessment module was evaluated properly so that the module produced can achieved the objectivity. The purposes of the study are as below:

1. Evaluate the validity level of the MoPPK module.

2. Evaluate the reliability level of the MoPPK module.

\section{Literature Review \\ Validity}

Validity refers to how accurately a method measures what it is intended to measure (Creswell, 2012). If research has high validity, that means it produces results that correspond to real properties, characteristics, and variations in the physical or social world. According to Russel (1974), the validity of a module should have five conditions, meeting the target; adequate time; can be implemented easily; capable of improving performance achievement; and modules can be taught to change students' attitude. The developed module is sent to the experts for the purposes of validation process.

\section{Reliability}

Reliability is the process after the validity test is completed (Creswell, 2012). Therefore, the reliability will be tested for the MoPPK module after validity test is run through experts' 
comments and opinions. Furthermore, the assessment in the module are expected to understand their mindset and behaviors: students would be more motivated instead of achieving higher performance. From the module, the researchers need to makes sure that the students understand well in every instruction made for every assessment in order to test the module assessments' reliability. Besides, the researcher can determine the students' extent of master of the module assessment's objectives by observing the performance at the end of evaluation. In conclusion, to achieve reliability coefficients of module's assessment, questions are designed based on the objectives of the module assessment (Jamaludin, 2008).

\section{Research Methodology \\ Research Design}

The design of the study is quantitative by using survey method. The validity of the modules is determined by the experts in the relevant field and the reliability of the module is determined by the students who involved in a module pilot study. There are thirteen experts were asked to validate the module for the content of the MoPPK module and eight experts for the language. The survey forms for content validity insists thirty items and language validity contain ten items. The experts were given questionnaires adapted by Russell (1974) which was translated by Sidek and Jamaludin (2005) with the rating scale 1 (strongly disagree) to 10 (strongly agree).

\section{Data analysis}

According to Sidek and Jamaludin (2005), a module has high content validity when earned $70 \%$ and is considered to have mastered or achieved a high level of achievement. To determine the level of validity of the module content, the total score that has been filled by the expert $(x)$ will be divided by the sum of the actual scores ( $y$ ) and multiplied by one hundred. Formula the following are as follows:

Total Expert Score $(x) \quad X 100 \%=$ Level of Module

Maximum Score (50) Percentage

The reliability of the module is determined by the student's assessment of the objectives learning to be achieved Questionnaires were then analyzed to obtain reliability values with using the Cronbach's alpha coefficient from SPPS software program. According to Konting (2000), if the value high reliability obtained, minimum of 0.60 means MoPPK Module has a good level of consistency. On the other hand, the value of reliability is not reaches a value of 0.60 , meaning the MoPPK Module is at a low level of consistency and needs improvement.

\section{RESEARCH FINDINGS}

Based on the analysis results, the remaining three experts only comment in general on the overall topics developed. In addition, results from expert evaluation, the validity value of the sub topic of the MoPPK module can be seen through table 1 below. 
Vol. 10, No. 1, 2021, E-ISSN: 2226-6348 @ 2021 HRMARS

Table. 1 Content Validity Value fof Sub Topic MoPPK Value

\begin{tabular}{lll}
\hline Topic & $\begin{array}{l}\text { Percentage } \\
\text { (\%) }\end{array}$ & Expert View \\
\hline $\begin{array}{l}\text { Personal and } \\
\text { Reproducitve } \\
\text { Health }\end{array}$ & 87.3 & Updated \\
$\begin{array}{l}\text { Substance } \\
\text { Abuse }\end{array}$ & 87.4 & Updated \\
Mental and & 88.2 & Updated \\
Emotional & & \\
Management & & \\
Family & 89.2 & Accepted \\
Relationship & 89.2 & Accepted \\
Disease & 90.0 & Accepted \\
Safety & 88.7 & Updated \\
Nutrition & 89.5 & Accepted \\
First Aid & 90.8 & Accepted \\
\hline
\end{tabular}

Based on Table 1, result shows the validity score for every subtopic in MoPPK module is between $\mathbf{8 7 . 3 \%}$ until $90.8 \%$. However, there are few subtopic that need to be update from the expert view which is Personal and Reproducitve Health (Score= 87.3\%), Substance Abuse (score=87.4\%), Mental and Emotional Management (score=88.2\%) and Safety (score= 88.7\%). The updating and improvement process is to make sure the implementation of this module is developed regularly with the learning objectives.

Table. 2 Percentage Analysis of Overall MoPPK Module Content Validity

\begin{tabular}{lcl}
\hline $\begin{array}{l}\text { Module Content } \\
\text { Aspects } \\
\text { The content of }\end{array}$ & $\begin{array}{c}\text { Percentage } \\
\text { (\%) }\end{array}$ & $\begin{array}{l}\text { Expert } \\
\text { View }\end{array}$ \\
this module... & & \\
\hline Cognitive & 88.7 & Accepted \\
Psychomotor & 88.3 & Accepted \\
Affective & 89.3 & Accepted \\
\hline Average & $\mathbf{8 8 . 7}$ & \\
\hline
\end{tabular}

Based on the Table 2, result shows the overall average of the modules and majority topics achieved good score between $88.7 \%$ until $89.3 \%$. This shows that the experts agreed that the module was developed appropriately to the content and meet the learning objectives. Overall, the validity of MoPPK module has a good average validity of $88.8 \%$ 
Table 3: Validity Statistics

\begin{tabular}{lcl}
\hline $\begin{array}{l}\text { Cronbach's } \\
\text { Alpha }\end{array}$ & $\begin{array}{c}\text { Cronbach's Alpha } \\
\text { Based on } \\
\text { Standardized } \\
\text { Items }\end{array}$ & $\begin{array}{l}\mathbf{N} \\
\text { Items }\end{array}$ \\
\hline .969 & .969 & 30 \\
\hline
\end{tabular}

Based on the table 3 validity statistics which have been obtained from test using SPSS .969 which is declared to have valid. Furthermore, all the three aspects in the module achieve good score which is more than $80 \%$. This means, the contents of the MoPPK Module is developed to coincide and in accordance with the objectives that have been outlined. However, even all the aspects of the content getting good scores but the panel still suggest to updated properly to enhance the learning objectivity with the assessment that has been developed.

For the language validity, the determination by the experts is based on the questionnaire given to validate the language used in the MoPPK module. Language validity assessment based on the expert panel is as follows:

Table 4: The language validity value of the MoPPK module

\begin{tabular}{|c|c|c|}
\hline Items & $\begin{array}{c}\text { Percentage } \\
(\%)\end{array}$ & Expert View \\
\hline Writing style & 83.8 & Accepted \\
\hline Instructions given & 85.0 & Accepted \\
\hline $\begin{array}{l}\text { Words used are } \\
\text { common }\end{array}$ & 80.0 & Accepted \\
\hline $\begin{array}{c}\text { Simple and } \\
\text { precise language }\end{array}$ & 81.3 & Accepted \\
\hline $\begin{array}{c}\text { Active words } \\
\text { used }\end{array}$ & 83.8 & Accepted \\
\hline $\begin{array}{l}\text { Sentences used } \\
\text { leads to the } \\
\text { aspect evaluated }\end{array}$ & 82.5 & Accepted \\
\hline $\begin{array}{c}\text { Sentences are } \\
\text { concise }\end{array}$ & 86.3 & Accepted \\
\hline $\begin{array}{c}\text { Sentences written } \\
\text { with open } \\
\text { statement }\end{array}$ & 85.0 & Accepted \\
\hline $\begin{array}{l}\text { Terms used } \\
\text { consistently }\end{array}$ & 86.3 & Accepted \\
\hline $\begin{array}{c}\text { Correct } \\
\text { grammatical and } \\
\text { spelling }\end{array}$ & 77.5 & Accepted \\
\hline
\end{tabular}

Table 4 shows the value of the language validity among expert evaluation. Eight experts give their comments through the statements given. Minimum percentage show is $77.5 \%$, which is statement in correct grammatical and spelling. While the statement for the sentences used are 
INTERNATIONAL JOURNAL OF ACADEMIC RESEARCH IN PROGRESSIVE EDUCATION AND

DEVELOPMENT

Vol. 10, No. 1, 2021, E-ISSN: 2226-6348 @ 2021 HRMARS

concise is maximum percentage which is $86,3 \%$.

Therefore, overall statement regarding language validity got a score above $70 \%$ which shows the language used in the module is acceptable.

Table 5: Reliability Statistics

\begin{tabular}{lll}
\hline $\begin{array}{l}\text { Cronbach's } \\
\text { Alpha }\end{array}$ & $\begin{array}{c}\text { Cronbach's Alpha } \\
\text { Based on } \\
\text { Standardized } \\
\text { Items }\end{array}$ & $\begin{array}{l}\mathbf{N} \\
\text { Items }\end{array}$ \\
\hline .825 & .827 & 60 \\
\hline
\end{tabular}

The Alpha Cronbach's analysis shows that the reliability of the module activity is very good, with the value of .825 in table 4. Alpha Cronbach values based on the substandard module content are also taken into account. Reliability test findings based on the learning objectives of the MoPPK Module conducted on students using Cronbach's alpha analysis is as in the table 6.

Table 6: Module Reliability Value Statement

\begin{tabular}{lcc}
\hline \multicolumn{2}{c}{ Statement } & Value, $\boldsymbol{\alpha}$ \\
\hline General & & .617 \\
Personal and & Reproducitve & .417 \\
Health & \\
Substance Abuse & & .955 \\
Mental and & Emotional & .853 \\
Management & & \\
Family & .504 \\
Relationship & .458 \\
Disease & .578 \\
Safety & .476 \\
Nutrition & .415 \\
First Aid & .676 \\
\hline
\end{tabular}

Based on table 6, all alpha coefficient values are in range between .415 to 0.955 , which means the validity of MoPPK module is in good state. The highest reliability value is the topic in Substance Abuse which is .955 and Mental and Emotional Management which is .853 . While, the lowest reading for reliability is .415 for the topic Nutrition. However, findings show that the reliability of the module is in very good range and acceptable and reliable to be used by the students and teachers. 


\section{Discussion}

\section{What is the validity level of the MoPPK Module?}

The module was evaluated by thirteen experts from various fields, namely module development, Sports Science, and language. Based on the score given by all the experts, overall the MoPPK module has a good validity with 88.7 percent with Alpha Cronbach .969. This shows that the instrument developed has measured what to be measured. The module also has been successfully developed to achieve its goals as the validity value of this module is more that 70 percent (Jamaludin, 2016). The validity value for the MoPPK module is 88.7 percent so it has been proved that it is good and effective. In addition, according to Zulkifli, Razak, and Mahmood (2018) statement that the modules developed using the ADDIE model have a validity value of more than 70 percent.

\section{What is the Reliability level of the MoPPK Module?}

The reliability process for the MoPPK module has been tested and the results of the Alpha Cronbach test analysis shows a good reliability value of .825 . By the reading of alpha values shows that the instrument is reliable and good (Putu \& Santiari, 2015). According to previous research, the instrument is sufficiently reliable if the value of Alpha Cronbach reaches .70 by using ADDIE model (Rahman, Ismail, \& Nasir, 2014). Therefore, the findings show that the development of the MoPPK module is acceptable.

\section{Conclusion}

As conclusions, it can be understood that the assessment of validity and reliability of modules are a process that needs to be done in building modules in education. Although the process of implementing these two assessments is complex and time consuming, but as a result of the suggestions, feedback and improvements obtained can further improve the quality of a module. At the same time, this evaluation process is also involved contribute towards the effectiveness aspect of a developed module. The researcher hopes that the MoPPK module can help teachers to assess student successfully in line with PAK 21. Moreover, it also can be useful to Ministry of Education to bring an outcome of a student balanced of physical, emotional, spiritual, intellectual and social

\section{Acknowledgment}

The author would like to express their highest appreciation to the panel of legal experts contents of the MoPPK Module, namely Associate Prof. Madya Dr Azali bin Rahmat (UPSI), Associate Prof. Dr Gunathevan a/I Elumalai (UPSI), Appreciation is also given to the academics who have provided guidance and guide in the process of development this module.

\section{References}

Rahmat, A., Jani, J., Salimin, N., Khalid, N.H.M., \& Salleh, O. (2012). COMPREHENSIVE ASSESSSMENT MODULE FOR FIRST AID IN PHYSICAL AND HEALTH EDUCATION. Index Copernicus Journal Master List, XII(1), 7.

Banta, T. W., \& Palomba, C. A. (2015). Assessment essentials:

Planning, implementing, and improving assessment in higher education. 
INTERNATIONAL JOURNAL OF ACADEMIC RESEARCH IN PROGRESSIVE EDUCATION AND

DEVELOPMENT

Vol. 10, No. 1, 2021, E-ISSN: 2226-6348 @ 2021 HRMARS

San Francisco, CA: Jossey Bass.

Creswell, J. W. (2012). EDUCATIONAL RESEARCH Planning, Conducting and Evaluating Quantitative and Qualitative Research. Sage Publication Vol. 66.

Jamaludin, A. (2008). Modul Dan Pengendalian Bimbingan Kelompok. Serdang: UPM.

Kementerian Pelajaran Malaysia. (2013). Kurikulum Standard Prasekolah Kebangsaan: Dokumen Standard Kurikulum dan Pentaksiran. Kuala Lumpur.

Konting, M. M. (2000). Kaedah Penyelidikan Pendidikan. Kuala Lumpur: Dewan Bahasa dan Pustaka.

Putu, N., \& Santiari, L. (2015). Embed Attitude from Student on Elearning Using Instructional Design with ADDIE Model, 6(11), 35-43.

Rahman, J. A., Ismail, M. A. H., \& Nasir, M. M. (2014). Development and evaluation of the effectiveness of computer-assisted physics instruction. International Education Studies, 7(13), 14-22.

Rossett, A. (1987). Training needs assessment. Englewood Cliffs: Educational Technology Publications.

Russell, D. J. (1974). Modular Instruction. A Guide to the Design, Selection, Utilization and Evaluation of Modular Materials. USA: Burgess Publishing Company.

Sidek, M. N., \& Jamaluddin, A. (2005). Pembinaan modul:

bagaimana membina modul latihan dan modul akademik.Serdang:

Universiti Putra Malaysia.

Smaldino, S. E., Lowther, D. L., \& Russell, J. D. (2012). Instructional Technology and Media for Learning. (10th Edition). Boston, MA: Pearson Education. https://doi.org/10.5539/ies.v7n13p14

States, J., Detrich, R., \& Keyworth, R. (2018). Summative Assessment ( Wing Institute Original Paper), (March). https://doi.org/10.13140/RG.2.2.16788.19844

Zulkifli, H., Razak, K. A., \& Mahmood, M. R. (2018). The Usage of ADDIE Model in the Development of a Philosophical Inquiry Approach in Moral Education Module for Secondary School Students, 2111-2124.

https://doi.org/10.4236/ce.2018.914153. 